AperTO - Archivio Istituzionale Open Access dell'Università di Torino

\title{
Criminal victimisation fosters conservatism among people living in areas with high unemployment rates: A multilevel longitudinal study
}

\section{This is the author's manuscript}

Original Citation:

Availability:

This version is available http://hdl.handle.net/2318/140251

since 2015-09-13T14:45:29Z

Published version:

DOI:10.1002/ejsp.1968

Terms of use:

Open Access

Anyone can freely access the full text of works made available as "Open Access". Works made available under a Creative Commons license can be used according to the terms and conditions of said license. Use of all other works requires consent of the right holder (author or publisher) if not exempted from copyright protection by the applicable law. 


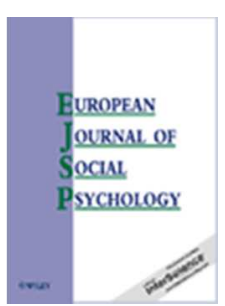

\section{Criminal Victimisation Fosters Conservatism Among People Living In Areas With High Unemployment Rates: A Multilevel Longitudinal Study}

\begin{tabular}{|r|l|}
\hline Journal: & European Journal of Social Psychology \\
\hline Manuscript ID: & EJSP-13-0019.R2 \\
\hline Wiley - Manuscript type: & Research Article \\
\hline \multicolumn{2}{l}{} \\
\hline
\end{tabular}

SCHOLARONE ${ }^{\text {m }}$

Manuscripts 


\section{Criminal Victimisation Fosters Conservatism Among People Living In Areas With High} Unemployment Rates: A Multilevel Longitudinal Study 


\begin{abstract}
Using a multilevel, longitudinal model, we tested the mugging thesis, which states that 'a conservative is a liberal who has been mugged', in a national sample of Italians $(N=457$, nested in 54 counties) surveyed four times between October 2002 and January 2007. We predicted participants' increase in conservatism as a function of the cross-level interactions between criminal victimisation on the one hand and the unemployment and the crime rates for their areas of residence on the other. Conservatism increased among victimised participants living in areas characterised by high unemployment rates, but not among those living in areas with low unemployment rates. The cross-level interaction between victimisation and crime rate did not influence our dependent variable. The strengths, implications and limitations of this research are discussed.
\end{abstract}

Keywords: conservatism, personal values, victimisation, voting behaviour, community 
Criminal Victimisation Fosters Conservatism Among People Living In Areas With High Unemployment Rates: A Multilevel Longitudinal Study

According to the assumptive world perspective (Janoff-Bulman, 1989), under normal conditions people tend to develop an image of the relationship between themselves and their social worlds based on three unquestioned assumptions: (a) the benevolence of the impersonal world and of other people; (b) the existence of a just, meaningful and controllable world; and (c) their own self-worth. Criminal victimisation, since it is based on the perpetrator's intention to cause harm (Craig-Henderson \& Sloan, 2003), is likely to jeopardise such assumptions. Hence, beyond its undesirable physical (Gidycz \& Koss, 1991) and economic (Van Dorn, 2004) consequences, victimisation may have negative psychological outcomes, fostering victims' senses of menace and psychological distress (Norris \& Kaniasty, 1994) and lowering their levels of well-being (Denkers \& Winkel, 1998). Thus, it is not surprising that people try to understand victimisation experiences and actively neutralise their negative effects through strategies such as denial of psychological and physical injury, acceptance of responsibility or appeal to higher motives (Warner \& Branscombe, 2011; Winkel, 1998).

In recent years, the idea that criminal victimisation can have political consequences, leading people to increase their degree of conservatism, has spread. At present, the mugging thesis, which states that 'a conservative is just a liberal who has been mugged' (King \& Maruna, 2009, p. 147), has become the equivalent of conservative folklore (Unnever, Cullen, \& Fischer, 2007). In this study we aimed to test the mugging thesis by focusing on the moderating effects of contextual features (i.e., threats) on the link between victimisation experiences and conservatism. 
The rationale behind the mugging thesis mainly relies on the simple assumption that people who are aware of the dangers of crime through first-hand experience (i. e., direct victimisation) tend to support policies hinged on law and order that are typically proposed by right-wing (conservative) parties (Danigelis \& Cutler, 1991; Tyler \& Boeckmann, 1997). This is because they believe those policies will mitigate crime. This idea resonates with the social psychological view of conservatism as motivated social cognition (Jost, Glaser, Kruglanski, \& Sulloway, 2003; Thorisdottir \& Jost, 2011). These authors argue that fear and threats can trigger the expression of conservative tendencies as people attempt to manage anxiety-inducing thoughts (Jost et al., 2003). In this light, conservatism should be considered, at least in part, as an ideological buffer that people may use to cope with environmental menace. Consistent with this idea, Napier and Jost (2008) showed that conservatives are systematically happier than liberals, plausibly because they are less exposed to the deleterious effects of rumination and introspection or because they are more able to rationalise the status quo. Following this line of reasoning, it is plausible that people might enhance their degree of conservatism to manage environmental uncertainty and threats from having been victimised.

Moreover, this would be consistent with ideas from the literature on the compensatory control mechanism (Kay, Whitson, Gaucher, \& Galinsky, 2009; Mirisola, Roccato, Russo, Spagna, \& Vieno, in press). According to this perspective, people can cope with the existential threat that comes from having low levels of perceived control over their environment (a typical consequence of criminal victimisation: see Jackson, 2011) by endorsing external systems that impose structure and order within their social worlds, including political forces that support the status quo. 
However, at present there is no solid evidence in favour of the mugging thesis. For example, Sears, Lau, Tyler and Allen (1980) showed that a composed index that integrated victimisation and fear of crime explained only $1 \%$ of the support for law-and-order policies. Moreover, Langworthy and Whitehead (1986), Stack (2000), and Unnever, Cullen and Fisher (2007) did not find any significant links between victimisation and participants' conservatism. Analogous results stemmed from research on the links between victimisation and punitiveness (Evans \& Adams, 2003; King \& Maruna, 2009; Stack, 2003). These studies looked only for direct effects (or for non-theoretically based interactive effects, see Unnever et al., 2007). However, victimisation can have interactive effects on social psychological outcomes. Indeed, it has recently been shown that victimisation fosters fear of crime only among people living in disadvantaged areas, in terms of perceived disorder - a variable strongly related to crime spread (Roccato, Russo, \& Vieno, 2011)—and unemployment rates (Vieno, Russo, \& Roccato, 2011). Thus, two different forms of community disadvantage have been shown to moderate the relationship between criminal victimisation and the fear of crime.

On the one hand, the moderating effect of perceived disorder has been discussed with regard to victimisation as an incentive for people to focus on the material and symbolic ecological cues of the environment in which they live. This makes the negative contextual aspects of their communities salient (Schultz \& Tabanico, 2009). Indeed, deeply inspecting advantaged communities does not foster fear of crime; the exploration of a non-disadvantaged community following a victimisation experience does not lead victims to find relevant signs of threats in their environment. On the contrary, victimisation experiences foster fear of crime among residents of disadvantaged communities, as such exploration leads them to see many signs of menace in their locales. Following this line of reasoning, contextual cues - considered in 
terms of either crime rate or disorder signals — should boost the effects of criminal victimisation. This argument is line with traditional criminological research (e. g., Bennett, Dilulio, \& Walters, 1996; Lupton \& Tulloch, 1999), which argues that psychological reactions to crime are substantially rational consequences from directly experiencing criminality. In this light, increased concern about crime following victimisation experiences should lead people with higher risks of being victimised again - i. e., those living in areas with high crime rates - to desire more law-and-order politics, and this would push them towards the right side of the political spectrum (Page \& Shapiro, 1992).

On the other hand, the moderating effect of the unemployment rate for a given area-considered synonymous with local socioeconomic disadvantage (Wilkinson \& Pickett, 2009) — is in line with a blend of traditional and critical criminologists' arguments. According to this view, social psychological reactions to crime following victimisation are the consequences of social and economic disadvantage (Mathieu, 1995). People feel vulnerable to events beyond their control, including crime (Franklin, Franklin, \& Fearn, 2008; Greenberg \& Paulsen, 1996; Roman \& Chaflin, 2008), and therefore are less able to cope with negative life events and less protected against many social anxieties, including those stemming from criminality (Hummelsheim, Hirtenehner, Jackson, \& Oberwittler, 2011). This perspective argues that living in a socioeconomically disadvantaged community should exacerbate the consequences of criminal victimisation experiences both because it enhances subjective vulnerability and anxiety and because it prevents crime victims from successfully coping with the negative events they have experienced. In this light, increased concern about crime after criminal victimisation should lead people who are particularly vulnerable to economic anxieties - those living in areas with a 
high unemployment rate - to have stronger desires for law and order, and that should push them to the right.

While these moderating effects of contextual conditions have been tested in research focused on the victimisation-fear of crime relationship (Roccato, Russo, \& Vieno, 2011; Vieno, Russo, \& Roccato, 2011), we are aware of just one study in which a conditional conception of the mugging thesis has been investigated. In a two-wave study performed at the individual level, Russo, Roccato and Vieno (2012) showed victimisation fostering participants' conservatism only among people living in large towns, i. e., environments characterised by high levels of social and physical disorder and high crime rates. However, Russo and colleagues' results had two main limitations.

First, their results were biased by the adoption of an individualistic perspective. Indeed, these authors used a contextual variable (the dimension of the town was considered at the individual level) as an individual characteristic instead of taking a multilevel perspective (Raudenbush \& Bryk, 2002). Three main ideas underlie multilevel analysis: (a) contexts are legitimate units of analysis, (b) contextual and individual characteristics are distinct, and (c) contextual variables may account for outcomes independently of individual variables or modify the relationships between individual variables and outcomes (Blakely \& Woodward, 2000; Diez-Roux, 1998; Lee, 2000). Indeed, by taking a multilevel approach, it is possible to disentangle the effects exerted on individual outcomes by the context from those stemming from individual variables, and to analyse the cross-level interactions between individual and contextual variables. Thus, multilevel models are particularly appropriate for research designs where, as in this case, the data for participants are nested (organized at more than one level). 
Second, the results by Russo and colleagues (2012) have been limited by their use of a simple two-wave longitudinal design. Indeed, repeated measurements should have been used to account for enduring trends. These limitations may be overcome by using three-level (longitudinal) multilevel models, which, although seldom used in research in social psychology, provide a very efficient analytic strategy for multivariate repeated measures of nested data.

Thus, in this study, we analysed the enduring cross-level interactive effects exerted by criminal victimisation and community disadvantage on participants' conservatism. By using a longitudinal multilevel approach, we investigated whether and to what extent the disadvantages of the counties where people live - in terms of crime rate and unemployment rate-moderate the relationship between victimisation and changes in individual conservatism.

\section{Goals and Hypotheses}

We performed a multilevel longitudinal study of the mugging thesis, testing two hypotheses. If, consistently with the traditional approach to social psychological reactions to crime, victimised people tend to be particularly sensitive to surrounding signs of possible new victimisation, the strength of the relationship between victimisation and conservatism should increase over time as a function of the crime rate in those participants' communities (HP1). If, consistently with a blend of the critical and traditional approaches, victimised people tend to be particularly sensitive to economic vulnerability, the strength of the relationship between victimisation and conservatism should increase over time as a function of the unemployment rate in those participants' communities (HP2).

\section{Method}

\section{Design}


We analysed the longitudinal data collected by the Observatory of the Northwest, a research institute at the University of Turin on a panel of Italians over the age of 14 between October 2002 and October 2007. For October 2002, September 2004, January 2006 and January 2007, data about participants' criminal victimisation and conservatism were available. We focused on the $454(52.0 \%$ women, mean age $=48.82, S D=18.68)$ people who participated in at least two waves; they were nested in 54 Italian counties. ${ }^{1}$

\section{Dependent Variable}

Each wave involved a question about participants' voting intentions. To quantify their positions on the left-right axis - the dimension that is most used for organizing perceptions about Italian political leaders and parties (Campus, 2000; Cavazza, Corbetta, \& Roccato, 2009), we used the 2006 ITANES (Italian National Election Studies) data, (www.itanes.org), in which a representative sample of the Italian population was interviewed about the positions held by the main Italian parties in terms of such an axis. As previously done by Lau and Redlawsk (1997), we considered the mean position given by the most politically expert participants of the ITANES sample as the parties' 'inter-subjective' positions. ${ }^{2}$ Table 1 presents the positions for the parties we considered. The higher the party's score, the higher its degree of conservatism. For our dependent variable, we used the change in the degree of conservatism for participants' voting intentions over time. Participants who did not express any voting intentions were excluded from the analyses.

\section{Predictors}

We used predictors at three different levels. At the within-individual level, we created a dummy variable for each wave to assess victimisation experiences: $0=$ participants who had not 
been victimised at all, and $1=$ participants who had been victimised at least once in the 12 months preceding the survey. This variable might vary for the four time points.

At the between-individuals level, we included five control variables from the 2002 survey: gender $(0=$ men, $1=$ women $)$, age, years of formal education, socio-economic status (SES) and the size of participants' areas of residence. Based on Corbetta, Cavazza, and Roccato (2009), we measured SES using four dummies expressing participants' social class_-bourgeoisie, white-collar, self-employed and blue-collar workers - and used unemployed people as reference category. For residency data, we used a dummy variable (coding 0 people living in towns with fewer than 100,000 inhabitants and 1 people living in larger towns).

At the ecological level, we used two variables gathered from the Italian National Institute of Statistics (ISTAT: www.istat.it) website and measured at the county level: (a) the official crime rate as the ratio between the entire number of crimes reported to police and the number of people living in each county; and (b) the unemployment rate as the number of unemployed residents within each county's population. The focus of our analysis was on the two cross-level interactions between criminal victimisation on the one hand and county crime and unemployment rates on the other.

\section{Analytic Strategy}

We ran a three-level hierarchical regression model using Hierarchical Linear Modeling software (HLM, Raudenbush, \& Bryk, 2002). The within-individual influence exerted on conservatism over time by direct victimisation was modelled at Level 1:

$$
\mathrm{Y}_{t i j}=\pi_{0 i j}+\pi_{1 i j}(\text { direct victimisation })+e_{t i j}
$$


In this equation, $t$ was the index for observation occasions, $i$ was the index for individuals and $j$ was the index for the county where they lived. We considered our victimisation variable a time-variable predictor (based on Raudenbush \& Bryk, 2002, we centred it), in that victimisation frequency could change over time.

Between-individuals conservatism variations were modelled at Level 2. The intercepts at Level 1 became the outcomes we tried to explain at Level 2:

$$
\begin{gathered}
\pi_{0 i j}=\beta_{00 j}+\beta_{01 j}(\text { age })+\beta_{02 j}(\text { gender })+\beta_{03 j}(\text { education })+\beta_{04 j}(\text { bourgeoisie })+\beta_{05 j}(\text { white- } \\
\text { collar } \left.)+\beta_{06 j}(\text { self-employed })+\beta_{07 j} \text { (blue-collar }\right)+\beta_{08 j}(\text { size of area of residence })+r_{0 i j}
\end{gathered}
$$

Finally, at Level 3, the variability of victimisation's effect was modelled as a function of the crime rate and of the unemployment rate after entering the principal effects of those variables (expressed at the third level as the effects they exerted on the variability of the intercepts-effects on $\left.\beta_{00 j}\right)$ :

$$
\begin{aligned}
& \beta_{00 j}=\gamma_{000}+\gamma_{001}(\text { crime rate })+\gamma_{002}(\text { unemployment rate })+u_{00 j} \\
& \beta_{10 j}=\gamma_{200}+\gamma_{201}(\text { crime rate })+\gamma_{202}(\text { unemployment rate })+u_{20 j}
\end{aligned}
$$

All the other parameters in the model were fixed. In order to clearly analyse the cross-level interactions, we used the simple slope technique as applicable (Bauer \& Curran, 2005).

\section{Results}

Table 2 presents the descriptive statistics for the variables we used and the correlations among them. ${ }^{3}$ As a whole, $11 \%$ of our sample participants had experienced victimisation. 
A preliminary unconditional model showed that $14 \%$ of the variation in conservatism was at the within-individual level, and $85 \%$ was between individuals within counties. The estimated county-level variation of the level of conservatism was not statistically significant, $\chi^{2}(53)=$ 49.56, $p>.500$. The within-individual influence that direct victimisation exerted on conservatism over time was modelled at Level 1 (see Model 1 in Table 3). Victimisation did not directly influence our dependent variable. However, since we found a significant random variance for the victimisation effect, $\chi^{2}(44)=79.01, p<.01$, we felt justified in formally testing our HP1 and HP2.

Conservatism variations between individuals were modelled at Level 2 (see Model 2 in Table 3). Only age was connected to these variations: Conservatism was shown to increase over time among older people. ${ }^{4}$

The three last columns of Table 3 (Model 3) show that, consistently with HP2, the cross-level interaction between victimisation and the unemployment rate was positively and significantly related to changes in the level of conservatism. However, contrary to HP1, the cross-level interaction between the crime rate and victimisation did not reach statistical significance $(p=.135)^{5}$

Figure 1 shows the relationship between victimisation and the variation in conservatism levels by county unemployment level. The histograms represent the within-individual relationship between direct victimisation and the level of conservatism, while the distance between the two histograms represents the difference in outcomes between a county at the $25^{\text {th }}$ and a county at the $75^{\text {th }}$ percentile for unemployment. Among victimised people, we found a consistent increase in conservatism among residents in counties with high unemployment rates. Based on Bauer and Curran's (2005) research, we verified that the conditional effect of 
victimisation on the variation in conservatism levels was not significant in counties with a low level of unemployment ( simple slope $b=.22, S E=.16, p=.31$ ), but positively and significantly related in counties with a high level of unemployment, (simple slope $b=.61, S E=.10, p<.05)$.

\section{Discussion}

In this study, we aimed to analyse how people's levels of conservatism changed based on the interaction between criminal victimisation and the degree of social disadvantage within the areas where participants lived. Generally speaking, we showed that criminal victimisation, beyond physical (Gidycz \& Koss, 1991), economic (Van Dorn, 2004) and psychological (Denkers \& Winkel, 1998; Koss, Woodruff, \& Koss, 1990; Norris \& Kaniasty, 1994; Resnik, 1987) consequences, may have relevant, enduring political effects. Consistently with previous research we found no main effect from victimisation on our dependent variable (Langworthy \& Whitehead, 1986; Sears et al., 1980; Stack, 2000; Unnever et al., 2007). Moreover, unlike what we expected in our HP1, we did not find a significant effect for the cross-level interaction between victimisation and the crime rates in participant counties. However, consistently with HP2, the cross-level interaction between victimisation and unemployment rates did foster participants' conservatism over time. Criminal victimisation led people living in counties with high unemployment rates to shift their voting intentions towards more conservative political parties, while no effect was found among people living in counties with low unemployment rates.

Thus, even though the literature lacks solid results in favour of the mugging thesis (King \& Maruna, 2009; Langworthy \& Whitehead, 1986; Sears et al., 1980; Stack, 2000), our results showed that the analysis of cross-level interaction effects among predictors may help to discover multilevel longitudinal links between victimisation experiences and conservatism. Indeed, 
victimisation per se was not sufficient to increase support for conservative parties. However, its political effects appeared under conditions of economic disadvantage.

Five main conclusions may be drawn from this study. The first two concern the social psychology of conservatism, two more make reference to other domains, and the last covers research performed in social psychology outside this domain.

First, our results indirectly confirmed that conservatism might be a 'consequence of worldview-enhancing cognitions motivated by the need to buffer with anxiety-inducing thoughts' (Jost et al., 2003, p. 249). Moreover, they supported the social psychological idea that the expression of conservative tendencies, besides being shaped by party identification (Campbell, Converse, Miller, \& Stokes, 1960), may vary by situation and motivation to overcome specific fears and threats (Jost et al., 2003). According to the authors into the compensatory control mechanism (Kay et al., 2009; Mirisola et al., in press), low perceived control levels foster the endorsement of political forces that support the status quo. Given that victimisation decreases one's perceived control over the environment (Jackson, 2011), new studies linking these two fields by analysing the relationship between threat and conservatism as mediated by perceived control could be interesting.

Second, the literature on terror management theory (Greenberg, Pyszczynski, \& Solomon, 1986; Stone, 2001) is somewhat inconsistent regarding the political effects of anxiety. On the one hand, according to some researchers, people can successfully cope with threats stemming from anxiety by adhering to values and views that dominate their society, i. e., raising their conventionalism (Florian, Mikulincer, \& Hirschberger, 2001; Rosenblatt, Greenberg, Solomon, Pyszczynski, \& Lyon, 1989). This is a construct strictly linked with conservatism (Adorno, Frenkel-Brunswik, Levinson, \& Sanford, 1950). However, other studies have shown a different 
effect: Threats led to a polarization of public opinion, making right-wingers more conservative and left-wingers more liberal (Anson, Pyszczynski, Solomon, \& Greenberg, 2009; Castano et al., 2011; Greenberg \& Jonas, 2003). As we did not find any main effects, our results have not been fully consistent with any of these lines of research. However, the moderated effect we detected resounded with the first more than the second.

Moreover, our results have been complementary with regard to two sets of studies. First, those by Thórisdóttir and Jost (2011) showed that threats indirectly foster conservatism through motivated closed-mindedness. Second, those by Langworthy and Whitehead (1986) and Zimring, Hawkins, and Kamin (2001) showed victimisation influencing people's conservatism through the fear of new victimisation and anger towards society for its inability to protect them. These studies did not account for any moderated effects, while we could not account for any mediators. Future multilevel research explaining the conditional link between victimisation experiences and conservatism by addressing and comparing the roles played by the fear of crime, resentment towards society and closed-mindedness as mediating variables would be germane.

Third, our results allowed us to participate in the debate about the nature of psychological reactions to crime, a dispute characterised by two main ideas. According to researchers taking a classic criminological approach (e. g., Lupton \& Tulloch, 1999), psychological reactions to crime are quasi-rational consequences of people's experiences with criminality. However, according to critical researchers (Franklin, Franklin, \& Fearn, 2008; Roman \& Chaflin, 2008; Vieno, Nation, Perkins, Pastore, \& Santinello, 2010; Vieno, Roccato, \& Russo, in press), such reactions primarily depend on people's social and economic vulnerability, in that concern for their neighbourhood's economic condition makes people feel vulnerable to events beyond their control, including crime (Greenberg \& Paulsen, 1996). Following this line of reasoning, 
psychological reactions to crime should be primarily considered as an umbrella sentiment which people develop to disguise their high levels of social and economic insecurity (Bauman, 1999), and such reactions should find their 'lived social meaning among people's senses of change, decay, optimism and foreboding in the neighbourhoods, towns, cities, and wider political communities in which they live and move' (Hope \& Sparks, 2000, p. 5). Our findings showed that victimisation experiences might influence political conservatism only in areas characterised by high unemployment rates. Thus, our results support a blend of the traditional and the critical approaches to psychological reactions to crime by highlighting that synergy between experiences with criminality and social and economic insecurity seems to be necessary for an increase in conservative endorsements.

Fourth, in spite of their emotional and subjective dimensions, psychological reactions to crime, far from being exclusively private psychological experiences, proved to be at least partially historically and socially specific. According to personality psychologists Lavine, Lodge, Polichak and Taber (2002), 'The political effects of personality do not occur in a contextual vacuum, but instead are magnified by the presence of key precipitating or 'activating' features of the political environment' (Lavine, et al., 2002, p. 344). Consistent with this idea, Mondak, Hibbing, Canache, Seligson and Anderson (2010) more recently stated that 'variation in people's psychological predispositions leads them to respond differently when exposed to common environmental stimuli, and, correspondingly, that the expression of personality traits will vary by situation' (p. 90). Although framed as a social psychology approach, our results agreed with this claim. Future multilevel studies aimed at testing it for other research topics will be interesting. The last implication of our study relates to research in social psychology, even that outside this field of study. According to Doise (1986), social psychological phenomena can be explained 
at the intra-individual, inter-individual, positional and ideological levels. Multilevel analyses allow researchers to take their studies one step further because such analyses can support predictions that simultaneously take individual and contextual independent variables and their cross-level interactions into account. We believe that research on social psychology would significantly benefit from multilevel analyses.

Our study had two limitations. First, our ecological data were compiled at the county level, which was broader than what we would have liked to use (street block or neighbourhood would have been preferable: see Perkins \& Taylor, 1996). Nonetheless, we still observed significant effects of contextual variables on our dependent variable. Moreover, this level of aggregation was consistent with previous Italian research on psychological reactions to crime (e. g., Russo, Roccato, \& Vieno, 2011, in press). However, a replication of this research performed at the street-block or neighbourhood level would be interesting. Second, the low variability of the crime rates at county level impels us to look at the results carefully, in particular the non-interactive effect of this variable in predicting conservatism. Future cross-national studies might help to create a clearer picture of this connection.

Despite the limitations noted above, our study had some strong points, mainly its longitudinal, multilevel approach and the quality of the sample we used. Indeed, it added to previous research by Russo and colleagues (2012) — which, to our knowledge, was the first empirical confirmation of the mugging thesis available in the literature - in three ways. First, the longitudinal nature of the data we analysed allowed us to examine how individual and contextual features impact people's conservatism over time. Second, the use of multilevel models allowed us to simultaneously consider intra- and inter-individual variables, as well as environmental predictors of changes in conservatism. Third, and most important for the aim of this study, our 
Victimisation and conservatism

multilevel approach allowed us to test cross-level interactions between individual and contextual variables. Moreover, from a theoretical point of view, we provided evidence that victimisation may have broad political consequences in terms of supporting conservative politics. Finally, from a methodological point of view, the literature shows that detecting interactive effects between predictors can give sophistication and maturity to the scientific literature (Aguinis, Boik, \& Pierce, 2001; Judd, McClelland, \& Culhane, 1995). In this study, we have shown that cross-level moderation analysis actually helped us to better explain the complex and enduring links between victimisation and political preferences, providing the first strong empirical confirmation of the mugging thesis. We believe our results should be considered useful starting points for new research on this topic. 


\section{References}

Adorno, T. W., Frenkel-Brunswik, E., Levinson, D. J., \& Sanford, R. N. (1950). The authoritarian personality. New York, NY: Harper.

Aguinis, H., Boik, R. J., \& Pierce, C. A. (2001). A generalized solution for approximating the power to detect effects of categorical moderator variables using multiple regression. Organizational Research Methods, 4, 291-323. doi: 10.1177/109442810144001

Anson, J., Pyszczynski, T., Solomon, S., \& Greenberg, J. (2009). Political ideology in the 21 st century : A terror management perspective on maintenance and change of the status quo. In J. Jost, A. C. Kay, \& H. Thórisdóttir (Eds.), Social and psychological bases of ideology and system justification (pp. 210-240). New York, NY: Oxford University Press.

Bennett, W. J., Dilulio, J. J., Jr., \& Walters, J. P. (1996). Body count: Moral poverty and how to win America's war against crime and drugs. New York, NY: Simon \& Schuster.

Blakely, T.A., \& Woodward, A.J. (2000). Ecological effects in multi-level studies. Journal of Epidemiology and Community Health, 54(5), 367-374.

Bauer, D.J., \& Curran, P.J. (2005). Probing interactions in fixed and multilevel regression: Inferential and graphical techniques. Multivariate Behavioral Research, 40(3), 373-400. Bauman, Z. (1999). In search of politics. Cambridge: Polity Press.

Campbell, A., Converse, P. E., Miller, W. E., Stokes, D. E. (1960). The American voter. New York, NY: Wiley.

Campus, D. (2000). Le conoscenze politiche dell'elettore italiano: Una mappa cognitiva (The Italian voters' political knowledge: A cognitive map). Rivista Italiana di Scienza Politica, $30(1), 89-125$. 
Victimisation and conservatism

Castano, E., Leidner, B., Bonacossa, A., Nikkah, J., Perrulli, R., Spencer, B., \& Humphrey, N. (2011). Ideology, fear of death, and death anxiety. Political Psychology, 32, 601-621. doi: 10.1111/j.1467-9221.2011.00822.x

Cavazza, N., Corbetta, P., \& Roccato, M. (2009). L'asse sinistra-destra e le sue euristiche: Cambiamenti in Italia, 1975-2006 [The left-wing axis and its heuristics: Changes in Italy, 1975-2006]. Psicologia sociale, 4(3), 455-465.

Corbetta, P., Cavazza, N., \& Roccato, M. (2009). Between ideology and social representations: Four theses plus (a new) one on the relevance and meaning of left and right. European Journal of Political Research, 48, 622-641. doi: 10.1111/j.1475-6765.2009.00845.x

Craig-Henderson, K., \& Sloan, L. R. (2003). After the hate: Helping psychologists help victims of racist hate crime. Clinical Psychology: Science and Practice, 10, 481-490. doi: 10.1093/clipsy/bpg048

Danigelis, N. L., \& Cutler, S. J. (1991). Cohort trends in attitudes about law and order: Who’s leading the conservative wave?. Public Opinion Quarterly, 55, 24-49. doi: 10.1086/269240

Denkers, A. J. M., \& Winkel, F. W. (1998). Crime victims' well-being and fear in a perspective and longitudinal study. International Review of Victimology, 5, 141-162. doi: $10.1177 / 026975809800500202$

Diez-Roux, A. V. (1998). Bringing context back into epidemiology: Variables and fallacies in multilevel analysis. American Journal of Public Health, 88(2), 216-222.

Doise, W. (1986). Levels of explanation in social psychology. Cambridge: Cambridge University Press.

Evans, T. D., \& Adams, M. (2003). Salvation or damnation? Religion and correctional ideology. American Journal of Criminal Justice, 28(1), 15-35. 
Florian, V., Mikulincer, M., \& Hirschberger, G. (2001). An existentialist view on mortality salience effects: Personal hardiness, death-thought accessibility, and cultural worldview defence. British Journal of Social Psychology, 40, 437- 453. doi:10.1348/014466601164911

Franklin, T. W., Franklin, C. A. \& Fearn, N. E. (2008). A multilevel analysis of the vulnerability, disorder, and social integration models of fear of crime. Social Justice Research, 21, 204227. doi: 10.1007/s11211-008-0069-9

Gidycz, C. A., \& Koss, M. P. (1991). Predictors of long-term sexual assault trauma among a national sample of victimised college women. Violence and Victims, 6(3), 175-190.

Greenberg, J., \& Jonas, E. (2003). Psychological and political orientation-The left, the right, and the rigid: Comments on Jost et al. (2003). Psychological Bulletin, 129(3), 376-382.

Greenberg, W. E., \& Paulsen, R. H. (1996). Moving into the neighborhood: Preparing residents to participate in a primary care environment. Harvard Review of Psychiatry, 4(2), 107-109. Greenberg, J., Pyszczynski, T., \& Solomon, S. (1986). The causes and consequences of the need for self-esteem: A terror management theory. In R. F. Baumeister (Ed.), Public self and private self (pp. 189-212). New York, NY: Springer.

Gidycz, C. A., \& Koss, M. P. (1991). Predictors of long-term sexual assault trauma among a national sample of victimised college women. Violence and Victims, 6(3), 175-190.

Hope, T., \& Sparks, R. (2000). Introduction: Risk, insecurity and the politics of law and order. In T. Hope \& R. Sparks (Eds.), Crime, risk and insecurity (pp. 1-9). London: Routledge. Hummelsheim, D., Hirtenehner, H., Jackson, J., \& Oberwittler, D. (2011). Social insecurities and fear of crime: A cross-national study on the impact of welfare state policies on crimerelated anxieties. European Sociological Review, 27, 327-345.doi: 10.1093/esr/jcq010 
Victimisation and conservatism

Jackson, J. (2011). Revisiting risk sensitivity in the fear of crime. Journal of Research in Crime and Delinquency, 48, 513-537. doi: 10.1177/0022427810395146

Janoff-Bulman, R. (1989). Assumptive worlds and the stress of traumatic events: Applications of the schema construct. Social Cognition, 7(2), 113-136.

Jost, J., Glaser, J., Kruglanski, A. W., \& Sulloway, F. J. (2003). Political conservatism as motivated social cognition. Psychologycal Bulletin, 129(3), 339-375.

Judd, C. M., McClelland, G. H., \& Culhane, S. E. (1995). Data analysis: Continuing issues in the everyday analysis of psychological data. Annual Review of Psychology, 46, 433-465. doi: 10.1146/annurev.ps.46.020195.002245

Kay, A. C., Whitson, J. A., Gaucher, D., \& Galinsky, A. D. (2009). Compensatory control: Achieving order through the mind, our institutions, and the heavens. Current Directions in Psychological Science, 18, 264-268. doi: 10.1111/j.1467-8721.2009.01649.x

King, A., \& Maruna, S. (2009). Is a conservative just a liberal who has been mugged? Exploring the origins of punitive views. Punishment and Society, 11, 147-169. doi: $10.1177 / 1462474508101490$

Koss, M. P., Woodruff, W. J., \& Koss, P. G. (1990). Relation to criminal victimisation to health perceptions among women medical patients. Journal of Consulting and Clinical Psychology, 58(2), 147-152.

Langworthy, R. M., \& Whitehead, J. T. (1986). Liberalism and fear as explanations of punitiveness. Criminology, 24, 575-591. doi:10.1111/j.1745-9125.1986.tb00391.x

Lau, R. R., \& Redlawsk, D. P. (1997). Voting correctly. The American Political Science Review, $91(3), 585-598$. 
Lavine, H., Lodge, M., Polichak, J., \& Taber, C. (2002). Explicating the black box through experimentations: Studies of authoritarianism and threat. Political Analysis, 10(4), 343361.

Lee, V. E. (2000). Using hierarchical linear modelling to study social contexts: The case of school effects. Educational Psychologist, 35(2), 125-141.

Lupton, D., \& Tulloch, J. (1999). Theorizing fear of crime: Beyond the rational/irrational opposition. British Journal of Sociology, 50, 507-523. doi:10.1111/j.14684446.1999.00507.x

Mathieu, J.-L. (1995). L’insécurité [Insecurity]. Paris: PUF.

Mirisola, A., Roccato, M., Russo, S., Spagna, G., \& Vieno, A. (in press). Societal threat to safety, compensatory control, and right-wing authoritarianism. Political Psychology. doi: 10.1111/pops. 12048

Mondak, J. J., Hibbing, M. V., Canache, D., Seligson, M. A., \& Anderson, M. R. (2010). Personality and civic engagement: An integrative framework for the study of trait effects on political behavior. American Political Science Review, 104, 85-110. doi: $10.1017 / \mathrm{S} 0003055409990359$

Napier, J. L., \& Jost, J. T. (2008). Why are conservative happier than liberals? Psychological Science, 19, 565-572. doi: 10.1111/j.1467-9280.2008.02124.x

Norris, F. H., \& Kaniasty, K. (1994). Psychological distress following criminal victimization in the general population: Cross-sectional, longitudinal, and prospective analyses. Journal of Consulting and Clinical Psychology, 62(1), 111-123.

Page, B. I., \& Shapiro, R. Y. (1992). The rational public: Fifty years of trends in Americans' political preferences. Chicago, IL: University of Chicago Press. 
Victimisation and conservatism

Perkins, D. D., \& Taylor, R. B. (1996). Ecological assessment of community disorder: Their relationship to fear of crime and theoretical implications. American Journal of Community Psychology, 24, 63-107. doi: 10.1007/BF02511883

Raudenbush, S. W., \& Bryk, A. S. (2002). Hierarchical linear models. London: Sage.

Resnik, P. (1987). Psychological effects of victimization: Implications for the criminal justice system. Crime and Delinquency, 33(4), 468-478.

Roccato, M., Russo, S., \& Vieno, A. (2011). Perceived community disorder moderates the relation between victimization and fear of crime. Journal of Community Psychology, 39, 884-888. doi: $10.1002 /$ jcop.20470

Roman, C., \& Chaflin, A. (2008). Fear of walking outdoors: A multilevel ecologic analysis of crime and disorder. American Journal of Preventive Medicine, 34, 306-312. doi: 10.1016/j.amepre.2008.01.017

Rosenblatt, A., Greenberg, J., Solomon, S., Pyszczynski, T., \& Lyon, D. (1989). Evidence for terror management theory: I. The effects of mortality salience on reactions to those who violate or uphold cultural values. Journal of Personality and Social Psychology, 57, 681690. doi: $10.1037 / 0022-3514.57 .4 .681$

Russo, S., Roccato, M., \& Vieno, A. (2011). Predicting perceived risk of crime: A multilevel study. American Journal of Community Psychology, 48, 384-394. doi: 10.1007/s10464010-9386-X

Russo, S., Roccato, M., \& Vieno, A. (2012). “A conservative is a liberal urban dweller who has been mugged": A longitudinal study on the links between victimization and voting preferences. In A. N. Hutcherson (Ed.), Psychology of victimization (pp. 193-204). New York, NY: Nova Publishers. 
Russo, S., Roccato, M., \& Vieno, A. (in press). Criminal victimization and crime risk perception: A multilevel longitudinal study. Social Indicators Research. doi: 10.1007/s11205-0120050-8

Schultz, P. W., \& Tabanico, J. J. (2009). Criminal beware: A social norms perspective on posting public warning signs. Criminology, 47, 1201-1222. doi: 10.1111/j.1745-9125.2009.00173.x

Sears, D. O., Lau, R. R., Tyler, T. R., \& Allen, H. M. (1980). Self-interest vs. symbolic politics in policy attitudes and presidential voting. American Political Science Review, 74(3), 670684.

Stack, S. (2000). Support for the death penalty: A gender-specific model. Sex Roles, 43(3-4), 163-179.

Stack, S. (2003). Authoritarianism and support for the death penalty: A multivariate analysis. Sociological Inquiry, 66, 267-284. doi: 10.1080/00380237.2003.10571228

Stone, W. F. (2001). Manipulacion del terror y autoritarismo [Terror manipulation and authoritarianism]. Psicología Política, 23(1), 7-17.

Thórisdóttir, H., \& Jost, J. (2011). Motivated closed-mindedness mediates the effect of threat on political conservatism. Political Psychology, 32, 785-811. doi: 10.1111/j.1467-9221.2011.00840.x

Tyler, T. R., \& Boeckmann, R. J. (1997). Three strikes and you are out, but why? The psychology of public support for punishing rule breakers. Law and Society Review, 31(2), 237-266.

Unnever, J. D., Cullen, F. T., \& Fisher, B. S. (2007). “A liberal is someone who has not been mugged": Criminal victimization and political beliefs. Justice Quarterly, 2, 309-334. doi: $10.1080 / 07418820701294862$ 
Victimisation and conservatism

Van Dorn, R. A. (2004). Correlates of violent and non-violent victimization in a sample of public high school students. Violence and Victims, 19, 303-320. doi: $10.1080 / 07418820802025181$

Vieno, A., Nation, M., Perkins, D. D., Pastore, M., \& Santinello, M. (2010). Social capital, safety concerns, parenting and early adolescents' antisocial behavior. Journal of Community Psychology, 38, 314-328. doi: 10.1002/jcop.20366

Vieno, A., Roccato, M., \& Russo, S. (in press). Is fear of crime mainly social and economic insecurity in disguise? A multilevel multinational analysis. Journal of Community and Applied Social Psychology. doi: 10.1002/casp.2150

Vieno, A., Russo, S., \& Roccato, M. (2011). Il tasso di disoccupazione della zona di residenza modera la relazione tra vittimizzazione e paura del crimine: Uno studio multilivello [The unemployment rate of the place of residence moderates the relationship between victimization and fear of crime]. Psicologia Sociale, (6)3, 375- 384.

Warner, R. H., \& Branscombe, N. R. (2011). Observers' benefit finding for victims: Consequences for perceived moral obligations. European Journal of Social Psychology, 41, 241-253. doi: 0.1002/ejsp.772

Wilkinson, R., \& Pickett, K. (2009). The spirit level: Why equality is better for everyone. London: Penguin.

Winkel, F. W. (1998). Fear of crime and criminal victimization: Testing a theory of psychological incapacitation of the "stressor" based on downward comparison processes. British Journal of Criminology, 38(3), 473-485.

Zimring, F. E., Hawkins, G., \& Kamin, S. (2001). Punishment and democracy: Three strikes and you're out in California. Oxford: Oxford University Press. 
Footnotes

1. In Italy, there are 110 counties. These are local governmental entities with jurisdictions that usually include numerous towns surrounding one main city. We were only able to use data from 54 of them. Indeed, some counties were founded only recently, and aggregate data for them are not available yet. Based on Maas and Hox's work (2005), we also excluded counties with fewer than 10 respondents.

2. The political expertise of our sample members was computed using the answers to five political knowledge questions. ('Who is the Italian Prime Minister?' 'How many members are there in the Italian Chamber of Deputies?') We considered participants who correctly answered all of these questions as the most politically expert ( $n=490$, or $24.4 \%$ of the whole sample).

3. Even if the negative correlation between unemployment and crime rates seems counterintuitive at first glance, it is in line with Cantor and Land's (1985) claim that the unemployment rate could be negatively related to the crime rate in that it influences the availability and vulnerability of criminal targets. Consistently with this claim, Philips and Land's (2012) recent analysis on U. S. aggregate data from 1978 to 2005 showed contemporaneous effects of unemployment on a variety of different crimes.

4. In order to verify the possible different effects of victimisation among people living in different areas (particularly large towns), we performed parallel analyses, entering the cross-level interaction between victimisation (at the within-individual level) and town size (at the betweenindividual level). The effect was not significant $\left(\beta_{110}=.04(.34), t=.108, p=.91\right)$. Moreover, this effect was not variant at the county level $\left(\chi^{2}(42)=46.90, p=.28\right)$. 
Victimisation and conservatism

5. In parallel analyses, we tested the significance of the effect exerted on our dependent variable by interactions between unemployment and the crime rate. Our result was not significant $\left(\gamma_{103}=.14(.21), t=.646, p=.52\right)$. 
Victimisation and conservatism

Table 1.

Political Placement on the Left-Right Axis for the Main Italian Parties, 2006

\begin{tabular}{lc}
\hline \multicolumn{1}{c}{ Party } & Mean placement \\
& $(S D)$ \\
\hline Rifondazione Comunista (Commonist Refoundation) & $1.32(1.78)$ \\
Democratici di Sinistra (Left-Wing Democrats) & $2.61(1.23)$ \\
Verdi (Green Party) & $2.90(1.48)$ \\
Partito radicale (Radical Party) & $2.94(1.42)$ \\
Margherita (The Daisy) & $3.58(1.44)$ \\
Unione Democratica di Centro (Centre Democratic Union) & $6.37(1.78)$ \\
Forza Italia (Let's Go, Italy) & $8.14(1.56)$ \\
Lega Nord (Northern League) & $8.46(1.59)$ \\
Alleanza Nazionale (National Alliance) & $8.96(1.34)$ \\
\hline
\end{tabular}


Table 2.

Within-Individual, Between-Individual and County-Level Variables: Descriptive Statistics and Correlations

\begin{tabular}{|c|c|c|c|c|c|c|c|c|c|c|c|c|}
\hline & & Desc & tives & & & & & Corre & ations & & & \\
\hline Variables & Mean & $S D$ & Min & $\operatorname{Max}$ & 1 & 2 & 3 & 4 & 5 & 6 & 7 & 8 \\
\hline Within individual level $(N=1,27$ & & 8 & & & & & & & & & & \\
\hline 1 Conservatism & 4.99 & 2.82 & 1.32 & 8.96 & - & & & & & & & \\
\hline 2 Direct victimisation & 0.11 & 0.32 & 0 & 1 & .05 & - & & & & & & \\
\hline Between individual level $(N=45$ & & & & & & & & & & & & \\
\hline 1 Age & 48.82 & 18.68 & 15 & 94 & - & & & & & & & \\
\hline 2 Gender $(1=$ woman $)$ & 0.52 & 0.50 & 0 & 1 & -05 & & & & & & & \\
\hline 3 Years of formal education & 10.97 & 3.98 & 0 & 18 & $-.16^{* *}$ & -.05 & 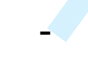 & & & & & \\
\hline 4 Bourgeoisie & 0.05 & 0.22 & 0 & 1 & .06 & .01 & -.05 & - & & & & \\
\hline 5 White-collar & 0.02 & 0.15 & 0 & 1 & .01 & -.03 & -.01 & -.04 & - & & & \\
\hline 6 Self-employed & 0.31 & 0.46 & 0 & 1 & .05 & .01 & .07 & $-.15 * *$ & $-.11 * *$ & - & & \\
\hline 7 White-collar & 0.07 & 0.26 & 0 & 1 & -.07 & -.03 & .04 & -.07 & -.05 & $-.20 * *$ & - & \\
\hline 8 Unemployed & 0.52 & 0.49 & 0 & 1 & .05 & .01 & -.06 & $-.24 * *$ & $-.18 * *$ & $-.70 * *$ & $-.31 * *$ & - \\
\hline
\end{tabular}




\section{Page 31 of 35}

European Journal of Social Psychology

Victimisation and conservatism

\begin{tabular}{|c|c|c|c|c|c|c|c|c|c|c|c|c|}
\hline 9 Size of the area of residence & 0.28 & 0.45 & 0 & 1 & .08 & .06 & .50 & $.08^{*}$ & .02 & -.04 & -.02 & -.01 \\
\hline \multicolumn{13}{|l|}{ County level $(N=54)$} \\
\hline 1 Crime rate & 0.04 & 0.02 & 0.02 & 0.10 & - & & & & & & & \\
\hline 2 Unemployment rate & 8.19 & .46 & 7.33 & 9.61 & $-.36^{* *}$ & - & & & & & & \\
\hline
\end{tabular}


Table 3.

Longitudinal Correlates for the Variations in Conservatism

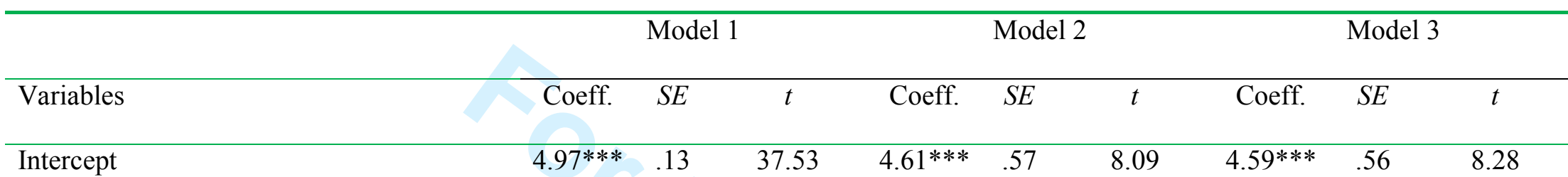

Level 1-Within individuals $(N=1,253)$

Victimisation

.24

1.44

$\begin{array}{lll}.21 & .15 \quad 1.41\end{array}$

.16

.15

1.07

Level 2-Between individuals $(N=450)$

Age

Woman

Education

Bourgeoisie

White-collar

Self-employed

White-collar

Size of the area of residence

$\begin{array}{cccccc}.01^{*} & .01 & 1.99 & .01 * & .01 & 1.97 \\ -.30 & .27 & -1.09 & -.32 & .28 & -1.14 \\ -.01 & .03 & -0.32 & -.01 & .03 & -0.21 \\ -.44 & .56 & -0.78 & -.49 & .56 & -0.88 \\ -.10 & 1.04 & -0.10 & -.12 & 1.07 & -0.12 \\ .14 & .25 & 0.53 & .10 & .25 & 0.42 \\ -.12 & .49 & -.025 & -.14 & .48 & -0.29 \\ -.01 & .28 & -0.04 & -.02 & .29 & -0.07\end{array}$




\begin{tabular}{|c|c|c|c|c|c|c|c|c|c|}
\hline Level 3-Between counties for & & & & & & & & & \\
\hline Crime rate & & & & & & & -11.24 & 10.67 & -1.05 \\
\hline Unemployment rate & & & & & & & -.01 & .07 & -0.57 \\
\hline Level 3-Between counties for & & & & & & & & & \\
\hline Crime rate & & & & & & & 10.98 & 9.19 & 1.19 \\
\hline Unemployment rate & & & & & & & $.19 *$ & .09 & 2.13 \\
\hline Variance components for $\pi_{0 \mathrm{ij}}$ & Var. & $S D$ & $\chi^{2}$ & Var. & $S D$ & $\chi^{2}$ & Var. & $S D$ & $\chi^{2}$ \\
\hline Within a single individual & 1.10 & 1.05 & & 1.06 & 1.03 & & 1.06 & 1.03 & \\
\hline Between individuals & 6.69 & 2.59 & $7421.02 * * *$ & 6.61 & 2.57 & $7026.67 * * *$ & 6.60 & 2.57 & $7018.22 * * *$ \\
\hline Between counties & 0.07 & 0.26 & 49.56 & 0.07 & 0.26 & 43.81 & 0.05 & 0.22 & 42.48 \\
\hline Between county for $\beta_{10 j}$ & & & & 0.34 & .58 & $76.26^{* * *}$ & .18 & 0.43 & $64.70^{*}$ \\
\hline
\end{tabular}

Note. In the table, we provided estimates with robust standard errors. The rough estimates, available upon request, were substantially analogous to those we presented. People who are not employed were used as the category of comparison. $* * * p<.001 .{ }^{* *} p<.01{ }^{*} p<.05$. 
1

2

3

4

5

6

7

8

9

10

11

12

13

14

15

16

17

18

19

20

21

22

23

24

25

26

27

28

29

30

31

32

33

34

35

36

37

38

39

40

41

42

43

44

45

46

47

48

49

50

51

52

53

54

55

56

57

58

59

60

Figure Caption

Figure 1. Moderation Effect of County's Unemployment Rate on the Association between Criminal Victimisation and an Increase in Conservatism. 
Figure 1.

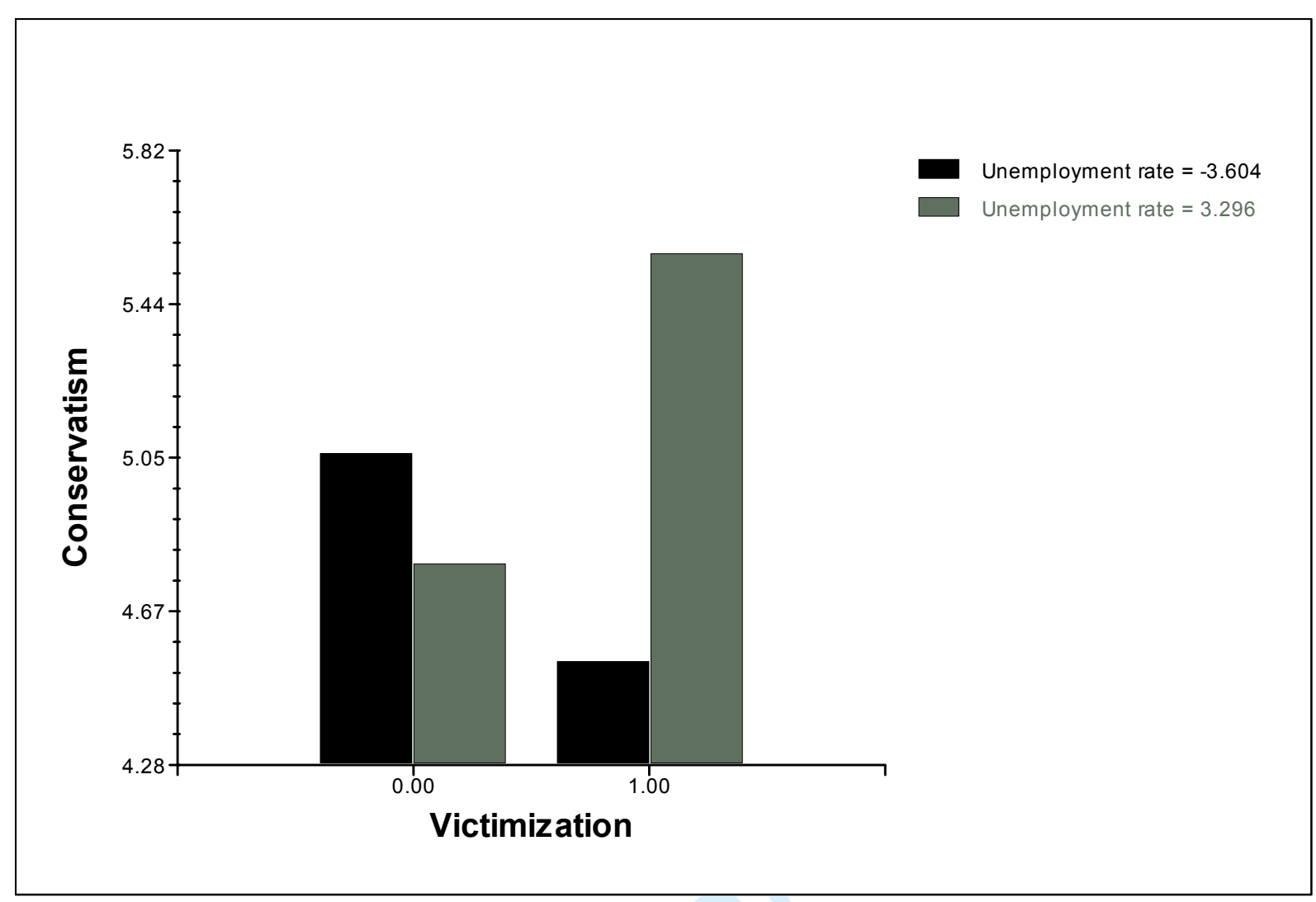

